\title{
THE TRANS-EUROPEAN TRANSPORT NETWORK (TEN-T): HISTORY, PROGRESS AND FINANCING
}

Summing up, the author, M.E.S. (Master in European Studies) MA (International Relations) Dipl.-Ing. (Transport Sciences), presents the basis of his actual doctor thesis about the international and strategic dimensions of the enlargement of the Trans-European Network (TEN) to Russia, the caucasus and Turkey. The article deals with the creation and the development of the TEN-T program of the European Commission. After the description of the history of this program, the progress of the fourteen transport priority projects is shown from the report of the Christophersen group to the European Council in 1994. In addition, the guidelines and the financial rules of the TEN-T are examined, which implemented a regular report from the member states to the Commission. With these data the financial forecast gets more realistic and further amendments about the construction progress could be made. Afterwards, the financing of the infrastructure projects is presented on the basis of the different European, government and private fundings. Finally an outcast is given about the new priority projects of 2004.

\section{Introduction}

In this article, history, guidelines on how to evaluate projects and budget figures of the European Union (EU) for the financing of the Trans-European Transport Network are presented. The data started with the development of the Common Transport Policy of the EU in the 1950's and continued with the establishment of the Trans-European Networks in 1992. Afterwards the progress of the TEN-T was evaluated. Therefore, the financing of the TEN-T is presented with its different sources, starting from the EU budget up to the different types of funds, loans and guarantees. Finally, there is an outlook from the High-Level group report on the identification of thirty new priority projects up to 2020 .

The Trans-European Networks were created with the foundation of the European Union and fixed in the Treaty of Maastricht in 1992. They include different modes of transport and are separated into (1) the TEN for energy and telecommunication and (2) the Trans-European Transport Network. The TEN-T includes air transport as well as road and rail networks. In addition, sea-transport is considered, divided into inland waterways (IWW), ports, and short-sea. Finally, better traffic management and navigation systems are TEN-T objectives. The so-called Intelligent Transport System (ITS) contains road traffic management, the European Rail Traffic management System (ERTS), traffic management and information of inland waterway navigation as well as the Vessel Traffic Management Information System (VTMIS). The ITS is completed by the Air Traffic Management (ATM) and the Global Navigation Satellite System (GNSS), which includes the Galileo satellite system.

\section{The History of the Trans-European Transport Network (TEN-T)}

The development of the European Common Transport Policy began long before the TEN. The first transport objective was already fixed in the Treaty establishing the European Coal and Steel Community (ECSC) in 1951 before being integrated in the Treaty of Rome, founding the European Economic Community (EEC) in 1957. This objective stated that "measures or practices which discriminate [...] in prices and delivery terms or transport rates and conditions" should "be abolished and prohibited within the Community" (ECSC, 1951, Title I Article 4). Six years later, the EEC went a step further and defined "a common policy in the sphere of transport" (EEC, 1957, Part 1 Article 3 f), which applied to the transport by rail, road and inland waterway, within the territory of the Community as well as to the international transport.

By the beginning of the 1980's, despite decades of economic prosperity and progressive integration of the European Communities (EC), the member states had failed to launch the Common Transport Policy. Therefore, the European Court of Justice, requisitioned by the European Parliament, admonished the Council in 1985 on account of its policy with respect to the liberalisation of the transport market (Kerwer, 2000, 12). According to this judgement the member-states changed their position, and the Council decided in 1988, proposed by the European Commission (COM), to introduce the Internal Market for transport (Bauchet, 1996, 48). But, while the increasing transport in the EU (see Fig. 1) necessitated action, further progress in the field of transport had to wait until the foundation of the European Union.

\footnotetext{
* B. Böttcher

C.E.I.E. (Centre d'études internationales et européenes), Université Robert Schuman, Strasbourg, France; E-mail: Boris.Bottcher@eturs.u-strasbg.fr
} 


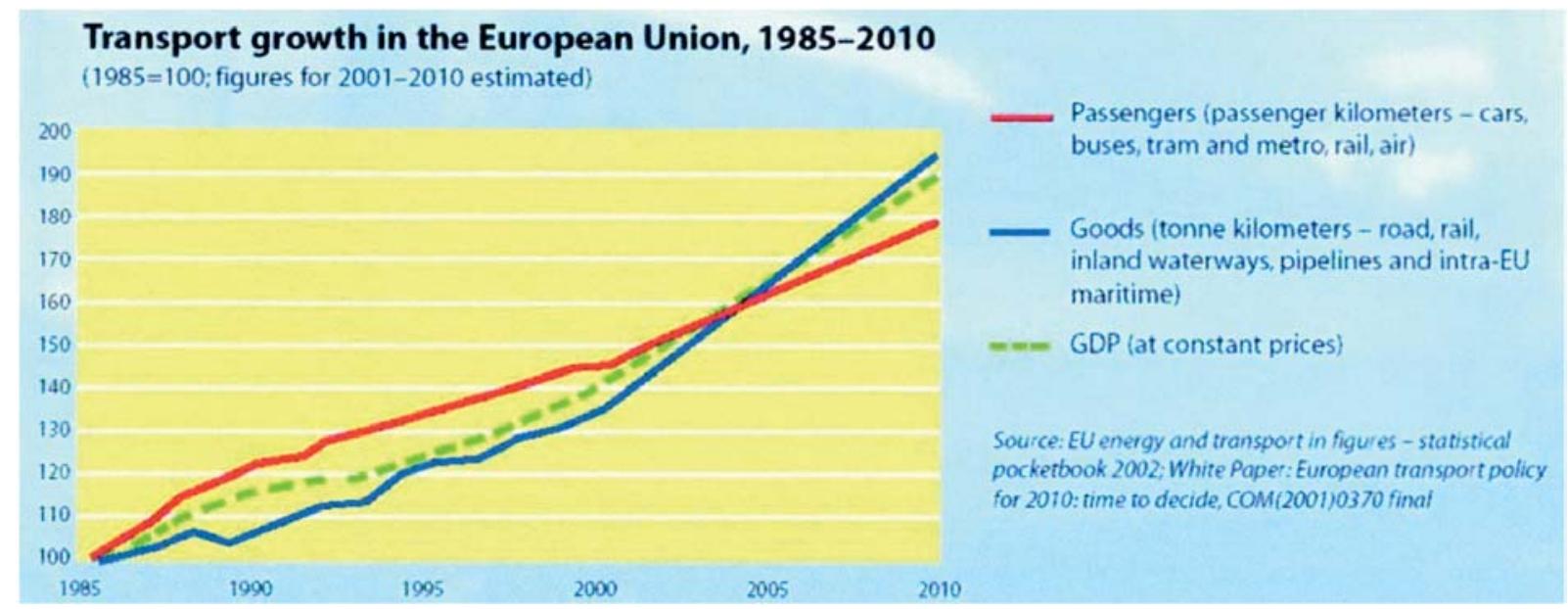

Fig. l: Trans-European Transport Network (COM, 2002, 5)

\section{The Progress of the Trans-European Transport Network}

Although some projects had begun previously, most of them were not started until the foundation of the European Union in 1992 (COM, 2004a). Due to the insertion of the Trans-European Networks in the treaty, the liberalisation of the transport market should be reached by promoting "the interconnection and interoperability of national networks as well as access to such networks" (EU, 1992, Article 129b). Therefore, coordination was needed, and the Council ordered a special group of national experts, led by the Vice-President of the Commission, Mr. Christophersen, to examine the possibilities to speed the progress of the TEN-T. In 1994, the propositions of the High-Level group included fourteen priority projects (EU, 1995a, Annex I, 254) as well as possible solutions for how to ease the rules of construction measures within the member-states and raise the needed financial aid. They were adopted in 1996.

Launching the network character of the measures, the amendments were focused on cross-border links and on projects that connect peripheral regions with the centres of the European Union. In particular, the high-speed train network was targeted with one of the main objectives, because the policy of the EU introduced the Strategic Environmental Assessment (SEA) in 1992, which strengthened the more durable transport modes. Fulfilling an obligation of the Article 129c of the Treaty of Maastricht (EU, 1992, Article 129c), the Community guidelines for the development of the Trans-European Transport Network were introduced in 1996 with the Decision 1692/96/EC (EC, 1996). This directive specified that the network must insure "sustainable mobility of persons and goods within an area without internal frontiers under the best

Total TEN-T support 1996 - 2001 in million $€$ per mode (Planco, 2003, 95)

Tab. 1

\begin{tabular}{|l|c|c|c|c|c|c|c|}
\hline & 1996 & 1997 & 1998 & 1999 & 2000 & 2001 & TOTAL \\
\hline Rail & 163.70 & 176.29 & 269.75 & 263.80 & 343.13 & 283.85 & $1,500.52$ \\
\hline Road & 27.77 & 49.82 & 59.50 & 62.96 & 73.40 & 83.00 & 356.46 \\
\hline Iww & 1.50 & 4.00 & 8.50 & 18.24 & 15.80 & 9.81 & 57.85 \\
\hline Airports & 3.78 & 21.45 & 28,60 & 29.36 & 11.10 & 14.73 & 109.02 \\
\hline Ports & 3.10 & 4,70 & 6.07 & 3.04 & 2.50 & 10.11 & 29.52 \\
\hline Combined transport & 0,31 & 0,00 & 1.80 & 9.40 & 1.50 & 1.30 & 14.31 \\
\hline Multimodal transport & 26.20 & 56.20 & 24.00 & 45.27 & 34.00 & 2.00 & 187.67 \\
\hline Air traffic management & 18.97 & 18.60 & 21.10 & 12.39 & 14.70 & 10.97 & 96.73 \\
\hline Road traffic management & 20.50 & 24,38 & $16 \mathrm{JO}$ & 15,68 & 32.13 & 25.29 & 134.89 \\
\hline Rail traffic management & 10.23 & 9.00 & 22.80 & 22.05 & 35.00 & 0.00 & 99.08 \\
\hline GNSS & 10.80 & 6.60 & 9.65 & 14.10 & 12.00 & 110.00 & 163.15 \\
\hline VTMIS (Vessel TM) & 2.14 & 0.96 & 5.34 & 1.30 & 0.90 & 0.00 & 10.64 \\
\hline TOTAL per year & 289.00 & 372.00 & 474.01 & 497.58 & 576.17 & 551.07 & $2,759.83$ \\
\hline
\end{tabular}


possible social and safety conditions" (EC, 1996, Section 1 Article 2 (2a)) and provided several other prerequisites to get accepted as priority projects of the TEN-T. Furthermore an "optimum combination and integration of the various modes of transport" should be guaranteed, so that all of these different modes of transport would be represented within the TEN-T. In addition to the willingness to strengthen the railways, every other mode was also supported directly by the Community budget (see Tab. 1).

\section{Financing of the Trans-European Transport Network}

Moreover, the decision of 1996 laid down in its Article 18 (3) the obligation to make an implementation report every two years and, from 1998 on, every four years. These reports had two main objectives. On the one hand, they present the figures about the progress of the projects, and, on the other hand, they expose the difficulties of one project or the changes in the circumstances. In this case, especially if financing of one project is in danger, the guidelines or the list of priority projects could be amended and updated. In the 2001 report, the Commission emphasized that, between 1996 and 2001, a total of $€ 172$ billion had been invested in the TEN-T with the sum for the railway being twice that of the total for the route infrastructure (COM, 2004b, p.8). The main question about all these infrastructure and technical measures is: how to finance all these projects? The Community policy is very strict with the direct financial aid: only $50 \%$ of the cost of preliminary studies (feasibility studies) and $10 \%$ of the cost of the work could be financed by the EU budget (EU, 1995b). Even though it was raised to $20 \%$ from 2003 (Regulation 1655/99), it is still far from full financing by the European Union.

Consequently, other Community resources must be found. In the first category of financing are different kinds of funds. The European Regional Development Fund (ERDF) had already existed when the Treaty of Maastricht established a Cohesion Fund effective at the end of 1993. This fund enabled EU financing of projects in countries in Objective 1 such as Portugal or Greece, which had a GDP below seventy five percent of the average EU-GDP, but also in the regions of the former GDR, at up to $100 \%$ of the project cost. In addition, loans and guarantees could be generated, like the newly created European Investment Fund (EIF), which could also be used for some transport projects. Overall, it was a great amount of money from Community funds to launch the TEN-T projects, primarily in the form of loans from the European Investment Bank (EIB), especially targeting the Central and Eastern Europe Countries (CEEC) - (see Tab. 2).

\section{The Current Situation and Outlook of the Trans-European Transport Network}

To summarize, the European Commission made great efforts to improve the European infrastructure, but the results for the Trans-European Transport Network in comparison to the forecast are disappointing. Two main problems are responsible for this development. On the one hand, the enlargement of the European Union widened the financial needs for the TEN-T. On the other

Community funding of TEN-T projects in million $€$ (see sources above)

Tab. 2

\begin{tabular}{|c|c|c|c|c|c|c|c|}
\hline Financing/ Year & $\begin{array}{l}\text { TEN-T Budget } \\
\text { (DG7) }\end{array}$ & $\begin{array}{c}\text { Cohesion Fund } \\
\text { (DG16) } \\
\text { (1993-1995 } \\
\text { calculated }\end{array}$ & $\begin{array}{c}\text { EIF } \\
\text { (loans/ } \\
\text { guarantees) }\end{array}$ & $\begin{array}{l}\text { EIB (loans) } \\
(1991-1994 \\
\text { with CEEC) }\end{array}$ & PHARE & $\begin{array}{l}\text { ERDF } \\
\text { (DG16) }\end{array}$ & $\begin{array}{c}\text { Total of year } \\
\text { or period }\end{array}$ \\
\hline 1991 & & for transport & & 2633 & & & 2633 \\
\hline 1992 & & $55 \%$ of total) & & 4868 & & & 4868 \\
\hline 1993 & 185 & 825 & & 4292 & 73 & & 5375 \\
\hline 1994 & 200 & 963 & & 4500 & 230 & & 5893 \\
\hline 1995 & 216 & 1100 & & & 240 & & 1316 \\
\hline 1991-1995 & 601 & 2888 & & 16293 & & & 19782 \\
\hline 1996 & 280 & 1224 & 303 & 3504 & 240 & - & 5311 \\
\hline 1997 & 352 & 1251 & 55 & 4943 & 240 & - & 6601 \\
\hline 1996-1997 & 632 & 2475 & 358 & 8447 & & 1050 & 12962 \\
\hline 1998 & 474 & 1337 & 72 & 4415 & 240 & - & 6298 \\
\hline 1999 & 497 & 1523 & 266 & 5977 & 240 & - & 8263 \\
\hline 1993-1999 & & & & & 1503 & & 1503 \\
\hline 2000 & 580 & 1287 & 117 & 4010 & & - & 5994 \\
\hline 2001 & 563 & 1318 & - & 5161 & & - & 7042 \\
\hline 1998-2001 & 2114 & 5465 & 455 & 19563 & & 3000 & 30597 \\
\hline 1991-2001 & 3347 & 10828 & 813 & 44303 & 1503 & 4050 & 64844 \\
\hline \multicolumn{2}{|l|}{ Sources: } & \multicolumn{2}{|c|}{ (Damien, 1999, 46-47) } & \multicolumn{2}{|c|}{ (COM, 2001a, 25) } & \multicolumn{2}{|c|}{$(\mathrm{COM}, 2004 \mathrm{c}, 25)$} \\
\hline
\end{tabular}


hand, and more importantly, historical privileges of national authorities for the planning of projects and policies of their national leaders often leave the projects uncompleted at the last miles before the border. As the Commissioner of Energy and Transport Loyola de Palacio pointed out in 2002, the problems are still not solved, and she resumed that "the resulting delays affect cross-border projects in particular. At the present rate, and without additional financing, further 20 years will be needed just to complete the work planned for 2010" (COM, 2002, 3). In addition, the financing remained difficult and insufficient (see supported actions COM, 2004d). While the European Commission often promoted only the beginning of transport projects, the planning or preliminary studies, the main efforts of the construction process were left for the member states. Therefore, the new proposal 2004/0154 (COD) of the Commission laying down general rules for the granting of Community financial aid wants "to change the co-financing rate to a maximum of $30 \%$ for certain sections of the priority projects, and that in exceptional cases for cross-border sections, to change the rate to a maximum of $50 \%$ (COM, 2004e).
For futher information about the TEN/T financing and perspectives see the recently published report (COM, 2005).

Substantial challenges remain. In 2003, only three of the old priority projects were finished and another five should be finished before the fixed date in 2010. But the rest of them will not be terminated by the 2010 goal, and 22 new priority projects are already in the pipeline, due to the report of the High-Level group. The costs for all these priority projects are estimated at up to $€ 235$ billion and the total sum for all Trans-European Networks through 2020 should be about $€ 600$ billion (all data COM, 2003). Summing up, beneath the challenge of the financial forecast, great efforts must also be made with regards to political decisions. While unanimity is no longer required in the transport sector, good consensus is more important than ever to safeguard a real network character of the TEN-T with the support of all EU countries.

\section{References}

[I] Treaty establishing the European Coal and Steel Community, 18 April 1951

[2] Treaty establishing the European Community, 25 March 1957

[3] KERWER, D., TEUTSCH, M.: Elusive Europeanisation - Liberalising Road Houlage in the EU, p. 12, http://www.mpp-rdg.mpg.de/ pdf_dat/00011.pdf, 23 Feb 2005

[4] BAUCHET, P.: Les transports de l'Europe - La trop lente integration, Paris, Economica, 1996, p. 48

[5] EUROPEAN COMMISSION: Trans-European Transport Network, p. 5, http://europa.eu.int/comm/ transport/themes/network/ doc/2002_brochure_ten_t_en.pdf, 17 Feb 2005

[6] http://europa.eu.int/comm/ten/transport/actions/supported actions_en.pdf, 28 Feb 2005

[7] Treaty on the European Union (Title XII Article 129b), 29 July 1992, http://europa.eu.int/eur-lex/lex/en/treaties/dat/! 1992M/htm/1 1992M.html, 13 Feb 2005

[8] EUROPAISCHE UNION: Transeuropaische Netze, Amt fur amtliche Veroffentlichungen der Europaischen Gemeinschaften (Afa), Luxemburg, 1995, p. 254

[9] PARLIAMENT AND COUNCIL: Decision No 1692/96/EC, 23 July 1996, http://europa.eu.int/eur-lex/lex/LexUriServ/LexUriServ.do?uri=CELEX:31996D1692:EN:HTML, 06 Jan 2005

[10] PLANCO, et. al.: TEN-Invest - Final report, planco, Essen, 2003, p. 95, 06 Feb 2005 http://europa.eu.int/comm/ten/transport/documentation/doc/2003_ten_invest_en.pdf

[11] EUROPAISCHE KOMMISSION, DG VII, Dienststelle TEN-V: Durchführung der Leitlinien 1998-2001, (Afa), Luxemburg, 2004, p. 8

[12] Regulation (EC) $n^{\circ}$ 2236/95 of the Council about TEN financial aid, 18 Sep 1995, http://europa.eu.int/smartapi/cgi/sga_doc?smartapi!celexplus!prod!DocNumber\&lg=fr\&type_doc=Regul ation\&an_doc=1995\&nu_doc=2236, 7 July 2005

[13] DAMIEN, M.-M.: La politique europeenne des transports, Paris, puf, 1999, pp. 46-47

[14] EUROPEAN COMMISSION: TEN-T report 1996-1997, 2001, p. 25, 16 Jan 2005, http://europa.eu.int/comm/transport/themes/ network/english/hp-en/grepdocs/bimprep.htm

[15] EUROPEAN COMMISSION: TEN-T report 1998-2001, 2004, p. 25, 11 Feb 2005, http://europa.eu.int/comm/ten/transport/documentation/doc/sec_2004_0220_en.pdf

[16] http://europa.eu.int/comm/ten/transport/actions/supported_actions_2004_en.pdf, 28 Feb 2005

[17] COMMISSION OF EC: Proposal amending Reg. (EC) $n^{\circ}$ 2236/95, 14 July 2004, 28 Aug 2005, http://europa.eu.int/eur-lex/lex/LexUriServ/site/en/com/2004/com2004_0475en01.pdf

[18] EUROPEAN COMMISSION: TEN-T report with up to 2020, 2003, 06 March 2005, http://europa.eu.int/comm/ten/transport/revision/hlg/2003 report kvm_en.pdf

[19] EUROPEAN COMMISSION: Networks for peace and development - Extension of the major trans-European transport axes to the neighbouring countries and regions, 13 December 2005, http://europa.eu.int/comm/ten/transport/external_dimension/doc/ 2005_12_07_ten_t_final_report_en.pdf 